\title{
Fasting Ontology in Pillars of Islam
}

\author{
Sara Afiqah Mohd Zailani ${ }^{1}$, Nurul Aswa Omar ${ }^{2}$, Aida Mustapha ${ }^{3}$, Mohd Hisyam Abdul Rahim ${ }^{4}$ \\ ${ }_{1,2,3}$ Fakulti Sains Komputer dan Teknologi Maklumat, Universiti Tun Hussein Onn Malaysia, Johor, Malaysia \\ ${ }^{4}$ Pusat Pengajian Umum dan Kokurikulum, Universiti Tun Hussein Onn Malaysia, Johor, Malaysia
}

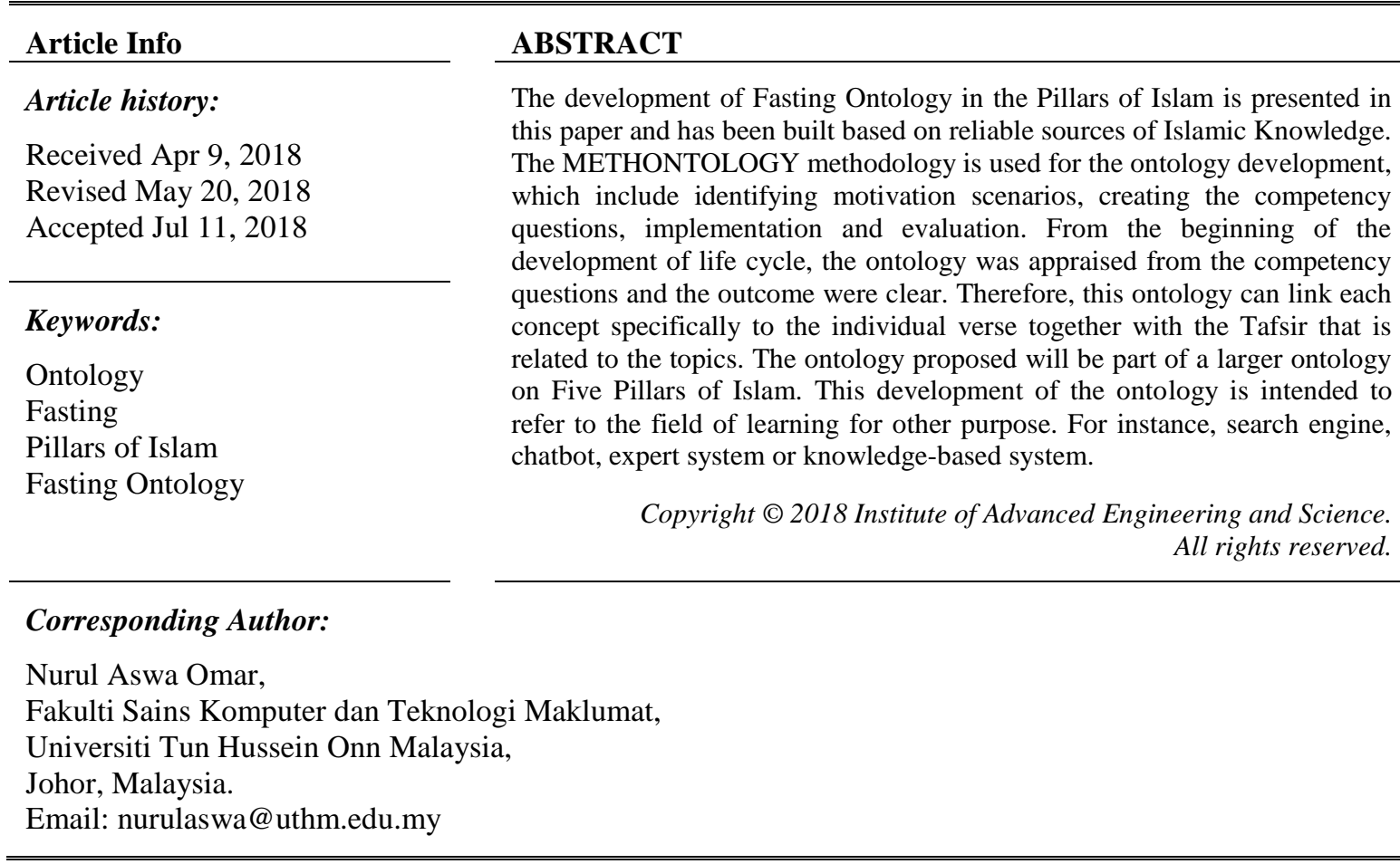

\section{INTRODUCTION}

In the Quran, Muslims are obliged to carry out all that is commanded by God and abandon anything that is prohibited by Him. Similarly, in the authentic Hadith, the Prophet summoned on Muslims to always worship to Allah. Therefore, there are no reasons for all Muslims to oppose Allah and His Apostle because all of it is noted in the Holy Quran. Looking at the 114 chapters that cover lots of themes as well as concepts in the Quran which is well-known as a Holy book, 6,236 verses contain the divine law also the Islamic knowledge. There are many verses in the Quran related to the fasting in Pillars of Islam. Pillars of Islam were mentioned in the Quran by Allah SWT. However, it is not stated in the order of Pillars of Islam itself because the verses in the Quran does not come according to a specific title. In other words, a lot of knowledge that comes from Quran must be searched chapter by chapter sequentially. There is a need to organize or rearrange the content of the Quran as well as the book of Tafsir into a form that can capture the relation between the keyword. In other words, a lot of knowledge that comes from Quran must be searched chapter by chapter sequentially.

As time passed, lots of Tafsir and translation that has content related to the Quran was divulged by Islamic scholars. With the existence of the computer software, a knowledge gained from rich contextual facts or information such as translation and Tafsir is essential. Humans as well as computers should understand the representation along with classification of knowledge resources to make sure the right representation of concepts and relation between concepts within the information technology environment. An ontology language is the formal language of an ontology development. According to [1], there are many ontology tools, such as OILEd [2], Protégé [3], TopBraid [4], Apollo [5], and KAON [6]. Although the ontology tools are a bit challenging also needed experience of knowledge to handle it, the construction becomes easier because of another mechanism in simplifying the production and visualization of the ontology. This study will develop an ontology based on Islamic knowledge to beyond the understanding of an ontology. The 
information must be sourced from the reliable source of Islamic knowledge, such as Quran, translation and Tafsir.

For the last 20 years, ontologies have received more attention in the world of research. Ontologies are being used in the different domains such as e-business, bio-informatics, integration, artificial intelligence, database design, intelligent information integration, and knowledge engineering. Ontology becomes a better way to collect information and to arrange them properly and specifically. If they are classified by using the computer and organized structure of an ontology is used, the speed and accuracy of the domain knowledge can increase, allowing the researchers to access them more properly and rapidly [7]. Ontology has also been widely used to represent concepts in many domains such as in education [8], [9] and business [10], [11].

A big consequence for researchers from investigation area of Expert System and Computer Science is to understand the Quran knowledge [12]. At present, ontology is used by researches to represent knowledge particularly in the field of the Quran, in a wider context. A system creating information that allows the knowledge of the Quran to be accessibly used by a lot of analyst and software developers [13]. The seminal work on Quran is the Quranic Ontology (http://52.174.242.246/) representing the Quran knowledge. This ontology connects various concepts to their associated verses in the Quran. Nonetheless, the existence of works that are relevant to the Quran Ontology are focusing on keywords or concepts in the Quran [14]. The ontology is neither sustained the contextual information by relating to the verses. Figure 1 shows the ontology concept of 'Islam', which only connected the concept to a certain verse and its translation.

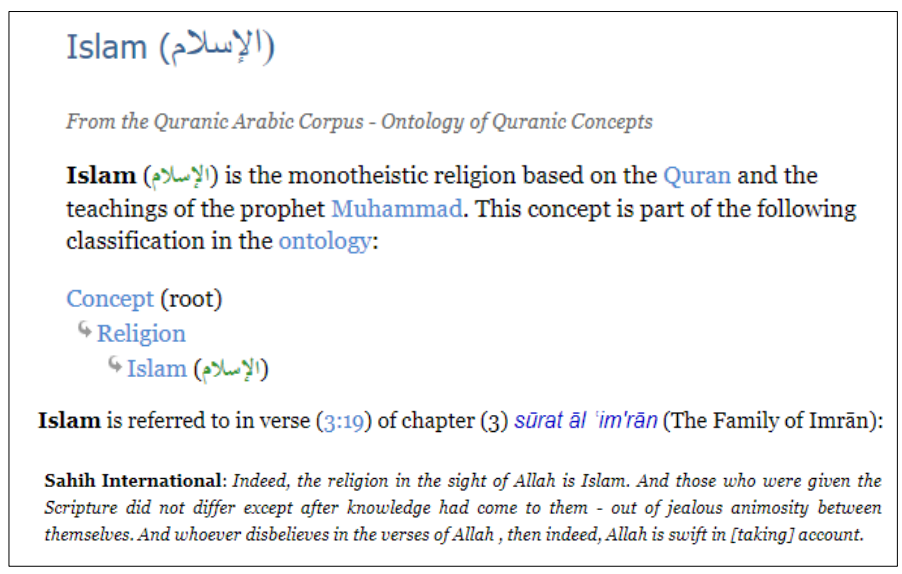

Figure 1. Passage of existing Ontology of Quranic Concepts

Contextual information is important for the translation of the verses correctly [14], [15]. In this study, domain expert has created manually contextual information which is Tafsir to support the concepts. Tafsir is an explanatory text body to make easier understanding of the definition of the correct verses. This is the future explanation of the verses that tell the background of the verse to be considered.

The aim of this paper is to describe how to develop the ontology in the Islamic Concept. the methodology comprising various of rules and techniques of extraction the concepts and to build the ontology of Fasting in Pillars Of Islam. This methodology inluded four phase such as identification of the motivation scenario, derivation of the competency questions, implementation and evaluation. The contribution of this research is develop new fasting ontology. Finally, the conclusion with some intimation for future work will be made after the development of the ontology.

\section{RESEARCH METHODOLOGY}

Nowadays, a lot of particular groups have developed ontologies, under particular approaches and using particular methods as well as techniques. The combination of the important information was gathered in the methodology development from Grüninger and Fox's methodology [16] and methodology of METHONTOLOGY [17]. Therefore, METHONTOLOGY methodology is used for the ontology development. METHONTOLOGY is one of the ontology model development methodology, where this method has an advantage related to the description of each activity to be done in details. METHONTOLOGY offers detailed execution of conceptualization activities at each stage and also has the ability to re-engineer ontologies. It shows clearly the steps improvements process along with the detailed life of development 
cycle. The recommended activity is execute including identifying motivation scenarios, deriving the competency questions, implementation of the ontology and evaluation. Figure 2 shows the METHONTOLOGY development life cycle.

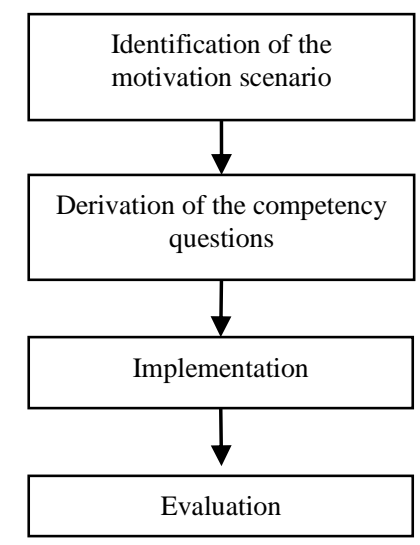

Figure 2. The METHONTOLOGY Development Cycle

\subsection{Identifying the Motivation Scenarios}

The ontology development is motivated by the applications that roll out by scenarios. A form of story problems always leads to a motivating scenario that are not competently handle appropriated by the subsisting ontologies. The motivation scenarios provide an intuitive set of possible results to the issues of scenario. All solution provides the beginning plan of the informal semantics for the items as well as relation that will then be inserted in the ontology. By using the use case in this motivation scenarios in object-oriented mechanism considering it is very user friendly and does not need advance skill to use it. Figure 3 shows the listing of motivation scenarios for Fasting Ontology in Pillars of Islam:

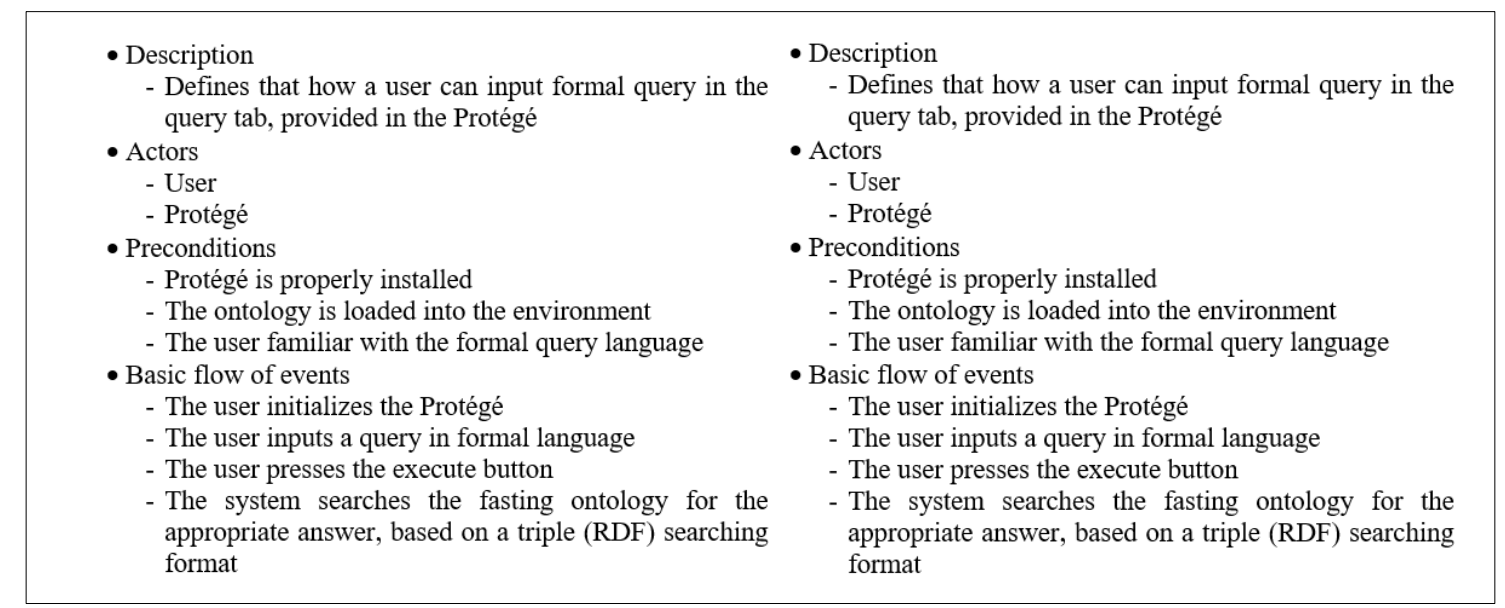

Figure 3. The Use Case of the Fasting Ontology

Hence, in this ontology development, the domain expert is using multiple sources including the Quran, translation and Tafsir.

\subsection{Deriving the Competency Questions}

One method to conclude the scope of ontology is the sketch of the basic menu in the ontologies based on the knowledge that needs to be answered through competency questions. A set of queries will derive on a concealed ontology demand for the given motivation scenarios. The questions have not yet been 
determined in the proper language of the ontology, hence they are informal questions. The competency questions do not develop ontological commitment.

However, they are function to assess the ontological commitment that will be built. They estimate the effectiveness of the ontology needed to represent the competency questions including identifying their results. The development of the ontology of this project will be tested by using competency questions that allow an ontology to show the relationship between the concepts and the verses in fasting. The informal questions in the ontology should be answered and wish to be availing to analyze the ontology according to their intention. During evaluation, the ontology is expected to give feedback this competency questions. The listing are the potential competency questions in domain fasting in Pillars of Islam.

1) Which verses are related to the concept of Kewajipan Puasa (Fasting Obligation)?

2) Which verses are belongs to surah Al-Baqarah?

3) Which verses are belongs to concept of Makanan (Food) and belongs to surah Al-An'am?

Referred to the listing of competency questions above, the ontology will contain all the information for fasting in Pillars of Islam. The user could understand the depth of knowledge for a specific area of expertise or domain after they go through the list of competency questions obtained from a specific domain.

\subsection{Implementation}

In the development of ontology based on fasting in Pillars of Islam that involves the types of fasting, condition, purification such as ghusl and other connected matters, including Quranic verses in Arabic language and translation. From the ontology development, the concepts, relationship properties, and instances have been generated shows in Table 1.

Table 1. Number of concepts, properties, and instances of Fasting Ontology in Pillars of Islam

\begin{tabular}{llll}
\hline & Concepts & Properties & Instances \\
\hline Number & 39 & 25 & 155 \\
\hline
\end{tabular}

The ontology will transform into a computable form using an ontological development tool after all the content of competency questions are finalized. The ontology for Fasting in Pillars of Islam was carried out by applying the Protégé which is an open source ontology editor and knowledge management system that provides a graphical user interface to determine ontology. Protégé's plugins architecture can be customized to build both simple and complex ontological based applications for instance Description Logic (DL) querying service. Figure 4 shows the classes of concepts for fasting. For instance, Keperluan (Requirement), Pembersihan (Purification), Terjemahan (Translation), Syarat (Condition) and Siyam (Fasting).

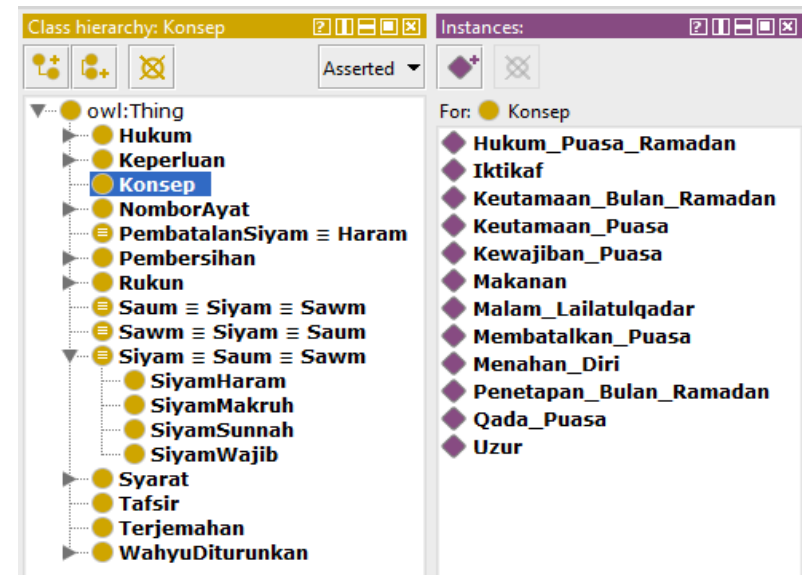

Figure 4. Classes of a new Fasting Ontology in Pillars of Islam

Figure 5 shows the relation between the concepts and the instances of the concepts. For instance, for the concept of Keutamaan Bulan Ramadan (Virtues of Ramadan) is linked to another concepts which is Malam Lailatulqadar (Night of Decree). The concepts of Malam Lailatulqadar (Night of Decree) is connected to contextual information in seven verses which is including two surahs. The verses will return the translation and Tafsir assosiated with the surah number 44 (Surah Ad-Dukhan-The Smoke) verse number 3 
and 4 and surah number 97 (Surah Al-Qadr-The Night of Power and Fate) verses number 1, 2, 3, 4, and 5. For example, the knot 97:1 returns the following translation and tafsir is correlated with this certain verse.

a. Translation: We have indeed revealed this (Message) in the Night of Power.

b. Tafsir: Verity, We have sent it down in the Night of Al-Qadr.

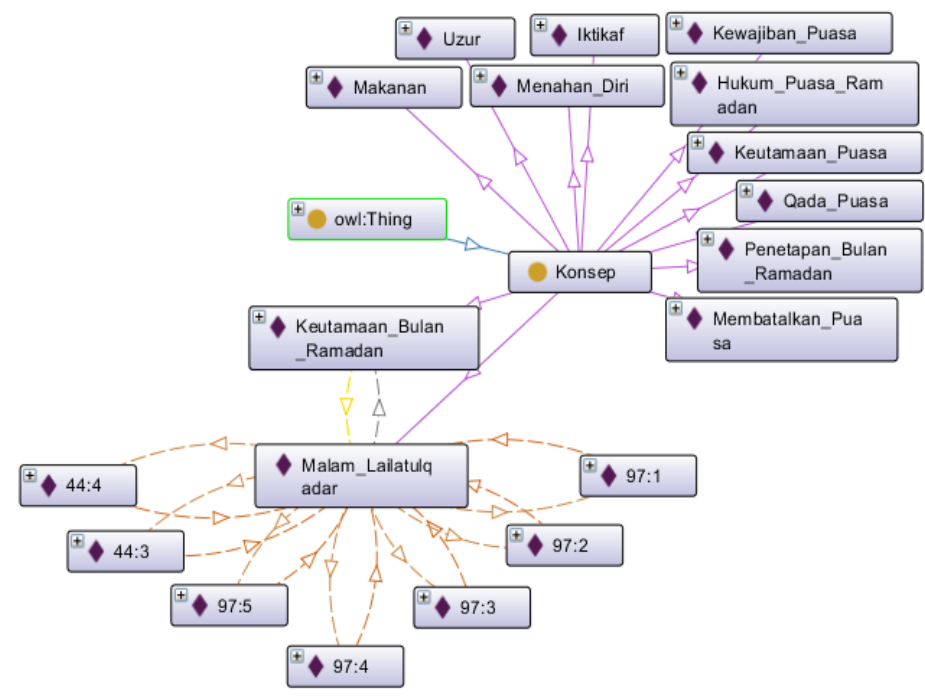

Figure 5. Relationship between the concept and their instances

Figure 6 shows the explanation of contextual information provided by knot 2:183, which shows surah number 2 (surah Al-Baqarah-The Cow) verse number 183.

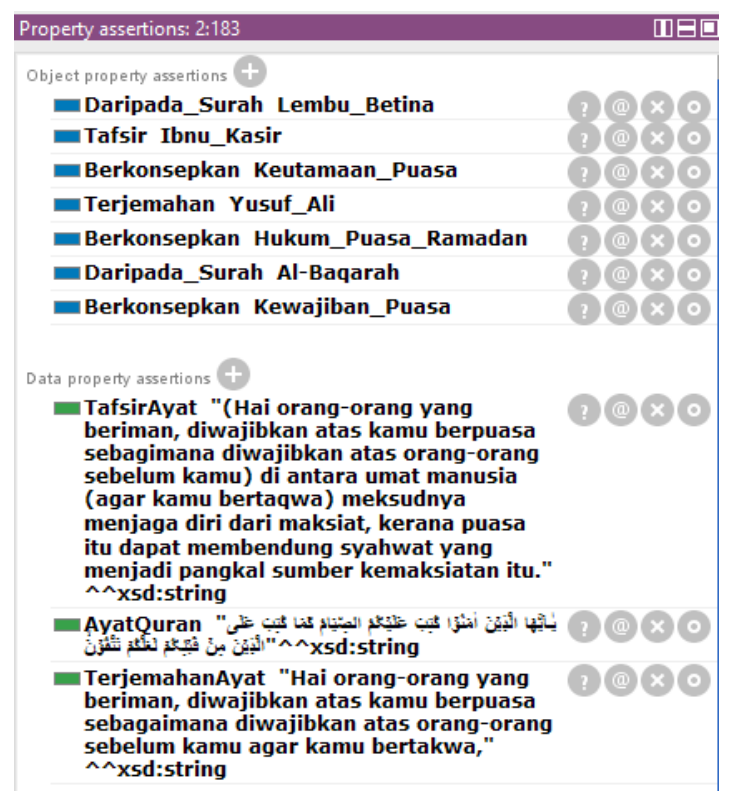

Figure 6. Details of contextual information provided by each verse

TafsirAyat is the Tafsir and TerjemahanAyat is the translation for this verse. Figure 7 shows the contextual information relation linked with the certain knot of 2:183, with the remaining of the concepts in the ontology. 


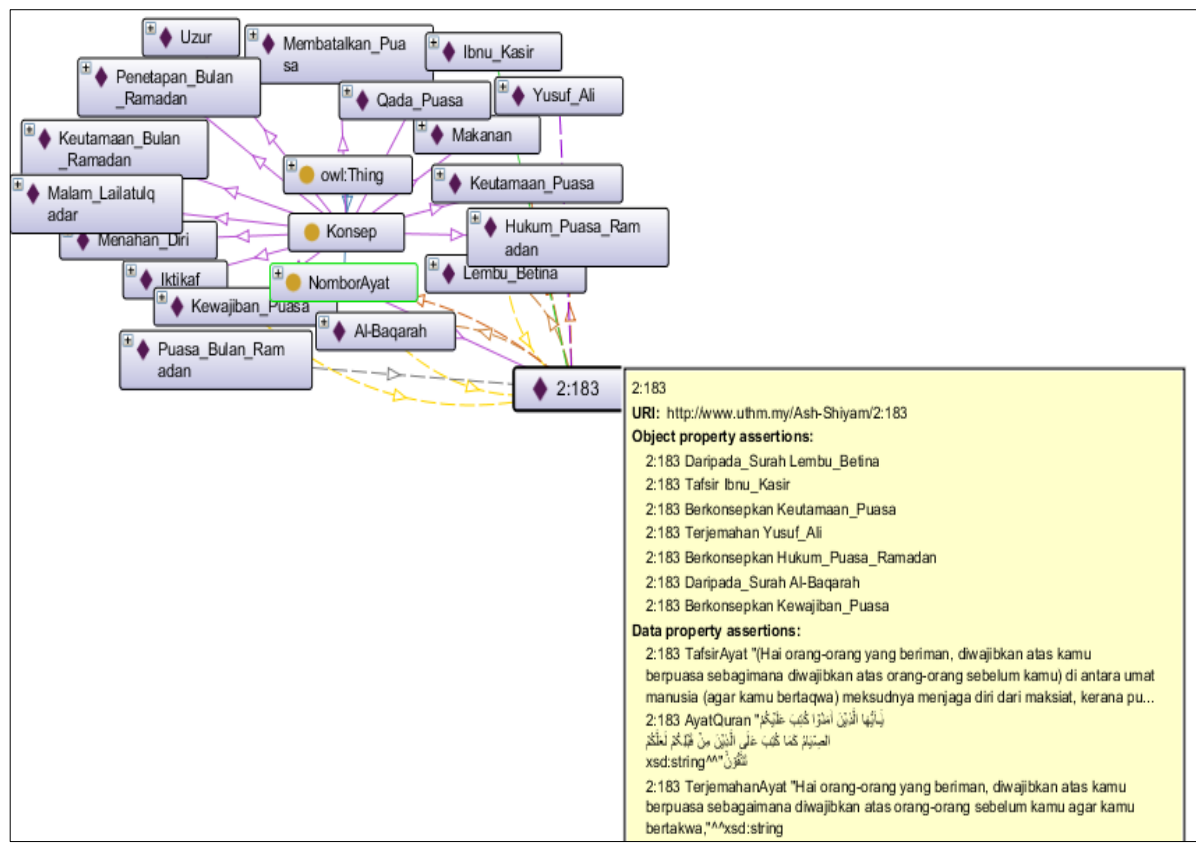

Figure 7. Contextual information provided by knot 2:183

Figure 8 illustrate the ontology section, generating from OntoGraf tab in Protégé focusing on four types of Fasting in Pillars of Islam such as Siyam Wajib, Siyam Sunnah, Siyam Makruh and Siyam Haram.

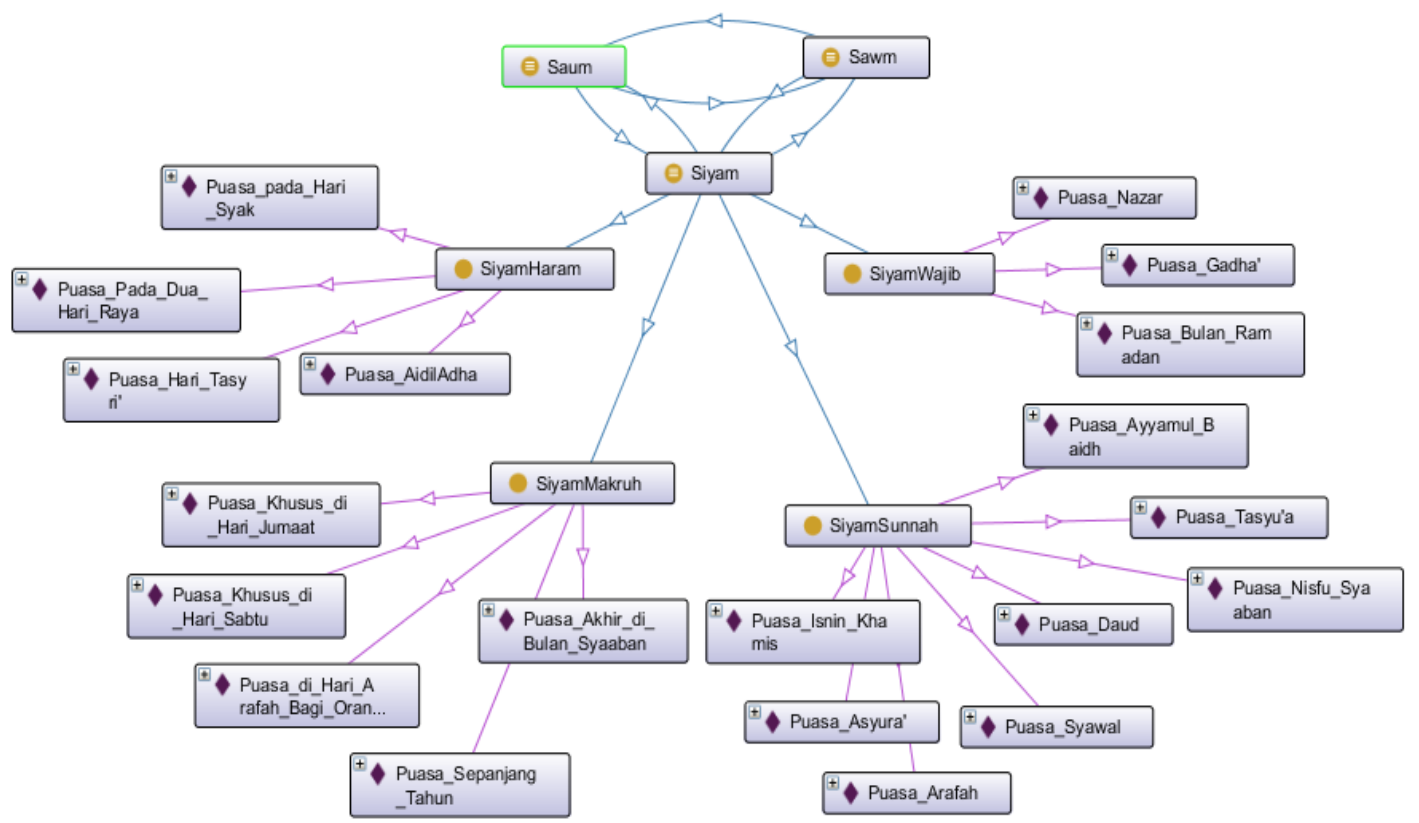

Figure 8. Visualization the Part of the Fasting Ontology

\subsection{Evaluation}

The next step after the ontology has been implemented in protégé, is to evaluate the ontology. This section is to verify that it accomplishes the objective of the development after the execution of an ontology in Protégé and correctly modeled based on their specific relationship to other concepts. The evaluation will show the satisfying results for the fasting ontology. The competency questions were created during the second step to perform the evaluation based on the METHONTOLOGY approach. 
However, competency questions have to be interpreted into their comparable representation in precise machine-level query language because it is prepared in natural language. SPARQL and the Description Logic (DL) are the formal query language in the Protégé.

The DL queries were entered in the DL query tab that available in Protégé. Users can create questions loaded ontology in the form of a DL query language in the query tab. The following part are the examples for competency questions and their equivalent DL queries.

i. Question 1: Which verses are related to the concept of Kewajipan Puasa (Fasting Obligation)?

Execute Query using Description Logic Query:

Berkonsepkan value Kewajipan_Puasa

ii. Question 2: Which verses are belongs to surah Al-Baqarah?

Execute Query using Description Logic Query:

Daripada_Surah value Al-Baqarah

Figure 9 show the answer of question 1 and figure 10 show the answer of question 2.

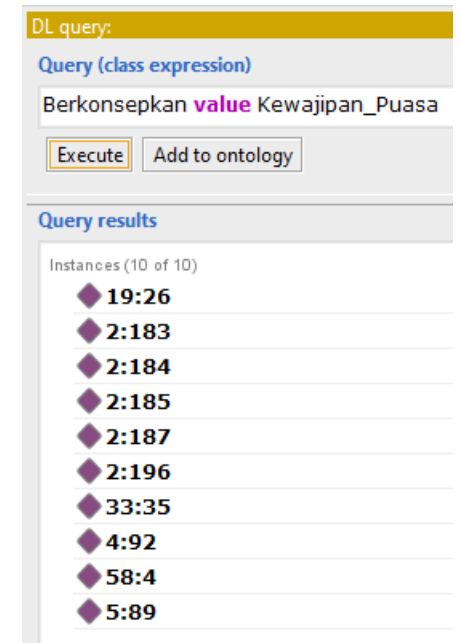

Figure 9. Answer question 1

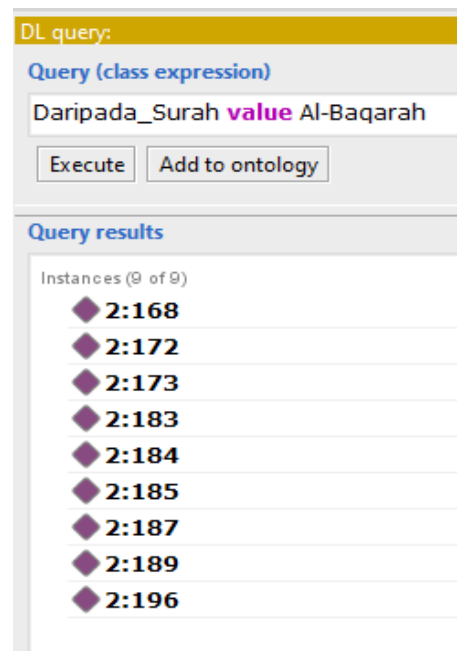

Figure 10. Answer question 2

iii. Question 3: Which verses are belongs to concept of Makanan (Food) and belongs to surah Al-An'am?

Execute Query using Description Logic:

Berkonsepkan value Makanan and Daripada_Surah value Al-An'am

Figure 11 show the answer of question 3.

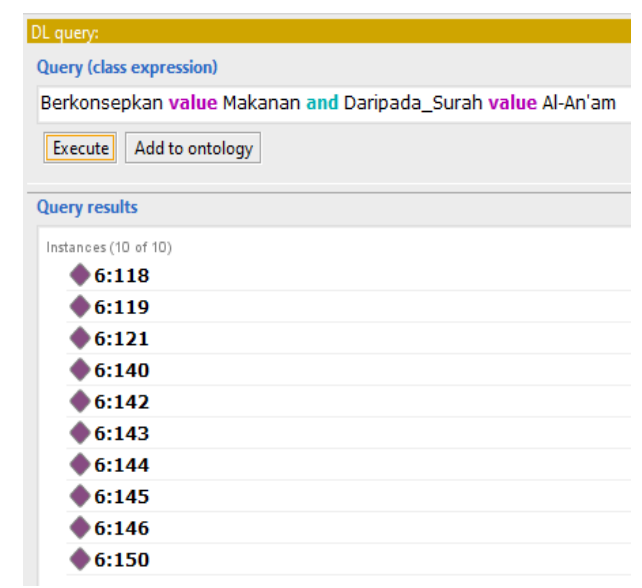

Figure 11. Answer question 3 
The DL Queries provided satisfying results for a new ontology for Fasting in Pillars of Islam shown in the evaluation. The development ontology assures to fulfill the requirement.

\section{CONCLUSION AND FUTURE WORKS}

A different Ontology have been stated for Fasting in Pillars of Islam that created manually based on expert knowledge, which represented concepts that exist from all verses of fasting. Quranic Ontology (http://52.174.242.246/) is the closest ontology for the Quran that is available to date. This development of the ontology was using the METHONTOLOGY methodology which made it more efficient and perceptive. The evaluation using the competency questions were provided by methodology, hence to ensure the relation among the concepts and the contextual information that domain expert serve was correct. The evaluation result was agreeable. In addition, the design of the ontology is flexible and can be drawn-out also altered plainly in the future to comprise more concepts Pillars of Islam in the Quran besides imitating into other languages.

\section{ACKNOWLEDGEMENT}

We would like to say thank you to Universiti Tun Hussein Onn Malaysia (UTHM) and Office for Research, Innovation, Commercialization and Consultancy Management (ORICC), UTHM for kindly proving us with the internal funding (Vot E15501).

\section{REFERENCES}

[1] Saidah Saad, N. Salim, H. Zainal, Z. Muda, "A process for building domain ontology: an experience in developing Solat ontology," International Conference on Electrical Engineering and Informatics, Bandung, Indonesia, pp. 1-5, 2011.

[2] Bechhofer, S., Horrocks, I., Goble C., and Stevens R., (2001). OilEd: A Reason-able Ontology Editor for the Semantic Web. Annual Conference on Artificial Intelligence KI 2001: Advances in Artificial Intelligence, pp 396408.

[3] Noy, N. F., Crubezy, M., Fergerson, R. W., Knublauch, H., Tu, S. W., Vendetti, J., Musen, M. A., (2003). AMIA 2003 Symposium Proceedings, pp. 953

[4] Emhimed Alatrish, (2013). Comparison Some of Ontology Editors. Management Information Systems, Vol. 8 (2013), No. 2, pp. 018-024.

[5] Lee, E., Harris, N., Gibson, M., Chetty, R., and Lewis, S., (2009). Apollo: a community resource for genome annotation editing, pp. 1836-1837.

[6] Bozsak, E., Ehrig, M., Handschuh, S., Hotho, A., Maedche, A., Motik, B., Oberle, D., Schmitz, C., Staab, S., Stojanovic, L., Stojanovic, N., Studer, R., Stumme, G., Sure, Y., Tane, J., Volz, R., Zacharias, V., (2002). KAON Towards a Large Scale Semantic Web. International Conference on Electronic Commerce and Web Technologies EC-Web 2002: E-Commerce and Web Technologies, pp. 304-313.

[7] Saidah Saad, N. Salim, H. Zainal, S. A. M. Noah, "A Framework for Islamic via Ontology Reprensetation," Proceedings of the International Conference on Information Retrieval \& Knowledge Management (CAMP), pp. 310314, 2010.

[8] Guangzuo, C. Fei, C. Hu, and L. Shufang, "OntoEdu: A Case Study of Ontology-Based Education Grid System for E-Learning," In GCCCE2004 International conference, Hong Kong, 2004.

[9] Alvino, S. Bocconi, P. Boytchev, J. Earp, and L. Sarti, "Sharing Digital Resources in Teacher Education: An Ontology-based Approach," 2009.

[10] Osterwalder and Y. Pigneur, "An e-Business Model Ontology for Modeling e-Business," $15^{\text {th }}$ Bled Electronic Commerce Conference e-Reality: Constructing the e-Economy Bled, Slovenia, 2002.

[11] Koschmider and A. Oberweis, "Ontology Based Business Process Description," 2005.

[12] Atwell, N. Habash, B. Louw, B. Abu Shawar, T. McEnery, W. Zaghouani, and M. El-Haj, "Understanding the quran : A new grand challenge for computer science and artificial intelligence," ACM-BCS Visions of Computer Science 2010, 2010.

[13] Abbas, "Quran'search for a concept'tool and website," Ph.D. dissertation, Citeseer, 2009.

[14] Husnah, A. Mustapha, and A. Alqurneh, "An Ontology for Juz' Amma based on Expert Knowledge," $7^{\text {th }}$ International Conference on Computer Science and Information Technology (CSIT), 2016.

[15] Iqbal, A. Mustapha, and Z. M. Yusoff, "An experiences of developing quran ontology with contextual information support," Multicultural Education \& Technology Journal, vol 7, no 4, pp. 333-343, 2013.

[16] Gruninger and M. S. Fox, "Methodology for the design and evaluation of ontologies," Proceedings of the Workshop on Basic Ontological Issues in Knowledge Sharing, 1995.

[17] Fernandez-Lopez, A. Gomez-Perez, and N. Juristo, "Methontology: from ontological art towards ontological engineering," AAAI-97 Spring Symposium on Ontological Engineering, pp. 33-40, 1997. 